\title{
FACTORS INFLUENCING ISLAMIC FINANCIAL INCLUSION IN INDONESIA: A STRUCTURAL EQUATION MODELLING APPROACH
}

\author{
Mohammad Mahbubi Ali* \\ Abrista Devi** \\ Hamzah Bustomi*** \\ Muhammad Rizky Prima Sakti**** \\ Hafas Furqani*****
}

\begin{abstract}
The study examines the determinants of Islamic financial inclusion in Indonesia by applying Structural Equation Modelling (SEM) and Binary Logistic Regression. Through a field survey across Indonesia's five main islands, the study gathered responses from 291 primary data samples. The study discovered that Islamic financial inclusion in Indonesia is determined by both the demand and supply sides. Two most significant determinants of Islamic financial inclusion in Indonesia from the demand side are financial literacy and social influence while on the supply side is human capital. The study also includes references and policy recommendations to help Indonesia's financial regulators in formulating effective policies and strategies to foster the country's Islamic financial inclusion agenda.
\end{abstract}

Keywords: Financial inclusion, Islamic finance, financial literacy, Indonesia, SEM, binary logistics.

\section{Introduction}

Financial inclusion has become the focus point and global agenda for many governments and central banks. Improving financial access is recognised as an essential enabler of development in the Sustainable Development Goals (SDGs) outlined by the United Nations Development Program (UNDP). Consequently, national governments around the world have implemented a variety of financial inclusion strategies and measures to improve access to financial services. ${ }^{1}$

Financial inclusion, in its most basic form, is an effort to ensure that financial products and services are accessible and affordable to all individuals and businesses regardless of their wealth and income. Financial inclusion, in this 
regard, would facilitate the lower segment of society to improve their economic situation and allowing them toparticipatein and benefit fromeconomic activities. ${ }^{2}$ People who have access to accounts, savings, and payment mechanisms can start and grow their businesses, manage risk, invest in productive sectors, and absorb financial shocks. ${ }^{3}$ In contrast, a lack of financial access may result in liquidity and payment issues, resulting in high fees associated with the usage of money orders or check-cashing services. ${ }^{4}$ It might also trigger a poverty trap due to a lack of opportunities to save when there is a liquidity surplus or to borrow when times are tough. ${ }^{5}$

Islamic finance, as a new segment of the finance industry, is often viewed as a promising sector that can help to address financial inclusion issues. According to the Global Findex, approximately 6 per cent of unbanked adults in developing countries do not have an account due to religious reasons. ${ }^{6}$ Islamic finance, a system that is founded on shariah rules and values, could bring people closer to financial access and enable them to use various shariah-compliant financial services. $^{7}$ The spirit of financial inclusion corresponds to the philosophical foundation of Islamic finance, which seeks to achieve equal access to financial institutions and promote equitable wealth distributions. ${ }^{8}$ The International Monetary Fund also acknowledged that "the growth of Islamic finance presents important opportunities to strengthen financial inclusion, deepen financial markets, and mobilise funding for development by offering new modes of finance and attracting unbanked populations that have not participated in the financial system."

In Indonesia, enhancing financial inclusion through Islamic finance is a top priority. Islamic microfinance sectors such as Baitul Maal wat Tamwil (BMT), Islamic cooperative institutions, Islamic pawnbrokers, and Islamic social finance institutions have evolved and played an important role in providing financial access to low-income communities over the last decades. In addition, the Indonesian government has made significant efforts and progress toward increasing financial inclusion. In this regard, the national strategy for financial inclusion was outlined in 2012 with a goal of achieving a financial system that is accessible to all Indonesian societies. Later, the Financial Services Authority of Indonesia - Otoritas Jasa Keuangan (OJK) launched the regulation of branchless financial services for financial inclusion (or known as "laku pandai"), which was stipulated on POJK 19 in the year 2014. In 2016, Bank Indonesia led the initiative to increase financial inclusion by introducing digital financial services to the unbanked population. ${ }^{10}$

Despite its efforts and progress, financial inclusion in Indonesia has yet to reach broad sectors of the population. The Global Findex discovered that only 48.9 per cent of adults in Indonesia have access to finance, leaving more than 
half (51.1 per cent) of them excluded from financial services; they do not have an account at any financial institution or access to a mobile wallet. According to a survey by OJK conducted in 2019 , the Islamic financial inclusion index was only 9.10 per cent, implying that only 9 persons out of 100 have benefitted from Islamic financial products and services.

The objective of this study is to identify possible idiosyncratic factors that may constrain low-income society's access to Islamic financial services. In particular, the present study will examine the determinants of Islamic financial inclusion in Indonesia from both the demand-side and supply-side.

The rest of this paper is laid out as follows. Section 2 depicts the financial inclusion theories and discusses the issues associated with financial inclusion. Section 3 discusses the research methods and data that were used. Section 4 encloses the results and analysis of the determinants factors of Islamic financial inclusion in Indonesia. Section 5 provides the conclusion and policy recommendations.

\section{Literature Review}

Several in the conventional finance literature studies investigated the determinants of financial inclusion. ${ }^{11}$ According to them, there is a significant relationship between financial inclusion and various factors, including sociodemographic factors (age, gender, living area, education, marital status, employment, and income), financial literacy, self-efficacy, infrastructure, documents, distance, and the cost of opening an account.

Regardless of the aforementioned, a good financial inclusion model should account for both the demand and the supply factors of financial inclusion. ${ }^{12}$ The demand factors include financial illiteracy, insufficient information about financial products and services, distrust in the financial system, religious constraints, and social factors. ${ }^{13}$ On the other hand, the supply factors are related to poor infrastructure of financial services, sophisticated document requirements, a lack of skills to understand the dynamics of financial services, the absence of robust credit information systems, and a lack of regulatory supports. ${ }^{14}$

Allen et al. argued that socio-economic variables, such as gender, age, living area, income, educational level, marital status, and employment status all have a significant impact on account ownership of Islamic financial services. ${ }^{15}$ Other research has found that socio-economic characteristics of households and socio-economic attributes of enterprises are essential determinants of financial inclusion. ${ }^{16}$ Socio-economic characteristics of the household included 
in the previous studies are gender, living area, financial literacy, income, annual household spending, education, per-capita income, and home ownership. Meanwhile, socio-economic characteristics of enterprises gathered in the previous literature are gender, living area, financial literacy, education, income, net profit of the business, annual household spending, and per capita spending.

A study by Kostov et al. discovered that financial literacy is an essential determinant of household behaviour in the decision-making process for financial products in South Africa. ${ }^{17}$ Similarly, Kimutai used some indicators to measure financial literacy, such as financial education, regular information updates, attendance of seminars, workshops, and use of mass media. The unbankedpeople's awareness of the importance of financial services is also influenced by their level of understanding and knowledge of financial products and services. ${ }^{18}$ Financial literacy is the term used to describe this level of understanding.

Religion is another important factor in determining financial inclusion. In the behavioural literature, there is increasing evidence that faith and ethnicity can influence financial literacy and decision-making. ${ }^{19}$ In the conventional finance literature, religious beliefs are associated with economic indicators. ${ }^{20}$ Guiso et al. explored the role of religion on people's economic attitudes. They discovered a link between religious beliefs and positive economic attitudes. Many verses in the Qur' an encourage Muslims to give their best effort to achieve the best result, therefore, economic underdevelopment in many Muslim majority countries may be due to political and legal factors rather than religious factors. ${ }^{21}$

According to a study by McClearly and Barro, economic growth depends on the extent of an individual's level of belief. Their study looked at how religious participation and beliefs affect the rate of economic progress in a country. The authors came to the conclusion that religious beliefs influence individual characteristic that improve economic performance. ${ }^{22}$

In the Islamic finance literat ure, Khan's research on the influence of religious beliefs on individual financial choices in Pakistan discovered that the 'faith premium' had a significant effect on the country's increasing demand for Islamic financial products and services. ${ }^{23}$ Zulkhibri later investigated the relationships between Islamic finance and financial inclusion in Muslim-majority countries. The findings suggested that many Muslim households are financially excluded from formal financial services due to religious concerns on the lack of shariahcompliant products and services. ${ }^{24}$

The latest work by Hassan et al. suggests that individuals in Muslim-majority countries are quite religious, implying a positive opportunity to boost Islamic banking penetration in that region. The paper also concludes that more religious individuals are less likely to use conventional financial services as a mean of borrowing since it violates the principles of shariah. ${ }^{25}$ 
Infrastructure is another factor influencing financial inclusion and a critical component to ensure that people have a better access to Islamic financial services and products. According to some studies, the lack of supporting infrastructure is a significant barrier to financial access in rural areas. ${ }^{26}$ Infrastructure readiness can be measured using three indicators: location, distance, and branding. ${ }^{27}$ Mobile banking infrastructure can be considered a significant determinant of financial inclusion..$^{28}$ Furthermore, branch expansion and ATM penetration for distance barriers can be used as proxies for infrastructure variables. ${ }^{29}$

Several studies have revealed that service quality has a significant impact on internet banking adoption in Malaysia. ${ }^{30}$ Customers are more likely to acquire banking products and services if the bank offers internet banking. ${ }^{31}$ Pricing is another aspect that affects product and services. Overpricing would create barriers to individuals engaging in banking products and services.

Furthermore, good communication and networking skills of banking staff are among the most effective persuasive ways to attract more participations in banking products and services. ${ }^{32}$ Therefore, human capital development is important to add value to the financial service industry. ${ }^{33}$ Poor human development and high financial illiteracy levels, on the other hand, may prevent a large number of people from benefitting from financial products and services. $^{34}$

Finally, we explored the importance of policies and regulations in promoting financial inclusion. Previous studies have empirically tested the impact of regulatory quality on financial inclusion. A country with high regulatory quality is more likely to have high levels of financial inclusion. ${ }^{35}$ In this regard, regulation would improve financial inclusion through financial innovation, regulatory framework, economic state, and financial sector stability in a country. ${ }^{36}$

From this literature review, the hypotheses of determinants of financial inclusion from both the demand and the supply factors can be derived as follows:

H1: Socio-economic variables significantly influence Islamic financial inclusion.

H2: Financial literacy significantly influences Islamic financial inclusion.

H3: Religious factors significantly influence Islamic financial inclusion.

H4: Social factors significantly influence Islamic financial inclusion. 
H5: Infrastructure significantly influences Islamic financial inclusion.

H6: Products and services significantly influence Islamic financial inclusion.

H7: Human capital significantly influences Islamic financial inclusion.

H8: Policies and regulations significantly influence Islamic financial inclusion.

\section{Data and Methodology}

\section{Data Collection}

A questionnaire was used to collect primary data from all respondents in various categories. This study includes 300 samples of respondents. The primary data came from a field survey conducted in five major islands in Indonesia, with one province serving as a representative for each island except Papua. Purposive sampling is used to select the representative provinces based on the highest financial inclusion indices in each island. The OJK financial inclusion database report is used as the basis to determine the sampling selection as it is the official publication by Indonesia's government. ${ }^{37}$ The province of Papua is excluded due to the small number of samples and low financial inclusion index.

We used stratified sampling and population data to determine the precise number of respondents for each representative area. According to the data from Indonesia's Statistic Centre (read: Badan Pusat Statistik/BPS, 2018), ${ }^{38}$ West Java have the highest total population $(12,895,640$ people), followed by South Sulawesi $(2,075,073)$, Aceh $(1,252,092)$, East Kalimantan $(864,128)$, and North Maluku (7,051 people). Therefore, the majority of our respondents are from West Java province.

Respondents are divided into several categories: (i) Islamic bank respondents, (ii) Islamic microfinance respondents, and (iii) Islamic capital market respondents. If the respondents have a formal IFI account or have access to savings, financing facilities, debit card, and insurance, they are classified as 'financially included respondents'. Respondents who do not have an IFI account or those facilities are classified as 'financially excluded respondents.' Table 1 illustrates the sample distribution of this study. 


\begin{tabular}{|c|c|c|c|c|c|c|c|c|}
\hline \multirow[t]{2}{*}{ Island } & \multirow[t]{2}{*}{ Province } & \multicolumn{2}{|c|}{ Islamic Bank } & \multicolumn{2}{|c|}{ Islamic Micro Finance } & \multicolumn{2}{|c|}{ Islamic Capital Market } & \multirow{2}{*}{$\begin{array}{c}\text { Total } \\
\text { samples } \\
\text { each } \\
\text { province }\end{array}$} \\
\hline & & Household & Enterprises & Household & Enterprises & Household & Enterprises & \\
\hline Sumatera & Aceh & 7 & 2 & 7 & 2 & 3 & 1 & 22 \\
\hline Java & West Java & 71 & 18 & 71 & 18 & 30 & 8 & 216 \\
\hline Kalimantan & Samarinda & 5 & 1 & 5 & 1 & 2 & 1 & 15 \\
\hline Sulawesi & Makassar & 11 & 3 & 11 & 3 & 6 & 1 & 35 \\
\hline Maluku & $\begin{array}{l}\text { North } \\
\text { Maluku }\end{array}$ & 2 & 2 & 2 & 2 & 2 & 2 & 12 \\
\hline \multicolumn{2}{|c|}{ Total } & 96 & 25 & 95 & 25 & 48 & 12 & 300 \\
\hline
\end{tabular}

Table 1: Respondents' Distribution Source: Authors

\section{Methodology}

This study uses structural equation modelling (SEM), a multivariate statistical technique, to analyse the causal relationships between variables using LISREL software. The SEM method, as mentioned by Hair et al. is appropriate for data in which the dependent variable for one regression analysis is also the regressors (independent variables) for another. SEM is derived from the simultaneous equation in econometrics (which includes measured or observed variables), but it also includes unmeasured variables (usually known as latent variables). ${ }^{39}$

SEM procedures include the following steps: (i) model specification, (ii) model identification, (iii) confirmatory factor analysis (CFA) for model measurement (involving, programming, estimation, test and modification, as well as re-specification if needed), (iv) path analysis for structural model (involving, programming, estimation, test and modification, as well as respecification if required), and v) interpretation and communication of the results.$^{40}$ Figure 1 depicts a summary of the SEM procedure. 


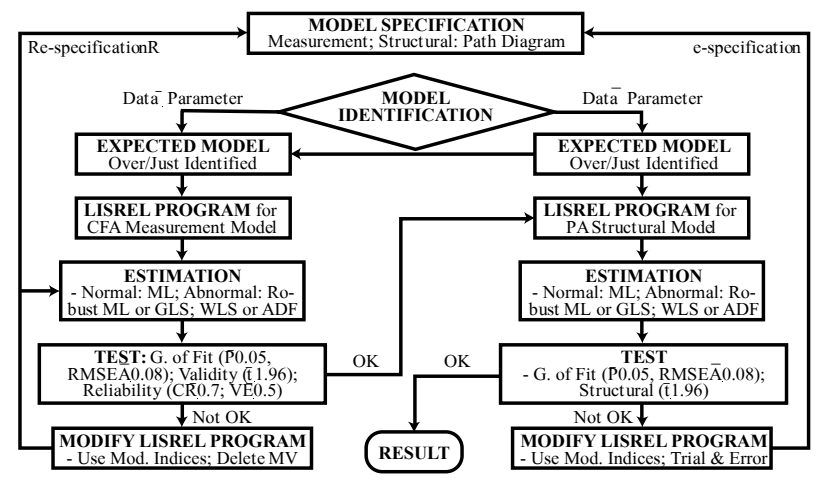

Figure 1: SEM Procedure Summary

Source: Ascarya (2013)

Where:

$\begin{array}{ll}\text { LF } & \text { : Loading Factor, } \\ \text { SLF } & : \text { Standardised Loading Factor, } \\ \text { MV } & : \text { Measured Variable, } \\ \text { LV } & \text { : Latent Variables, } \\ \text { RMSEA } & \text { : Root Mean Square Error of Approximation, } \\ \text { CR } & : \text { Construct Reliability, } \\ \text { VE } & : \text { Variance Extracted, } \\ \text { CFA } & : \text { Confirmatory Factor Analysis, } \\ \text { ML } & : \text { Maximum Likelihood, } \\ \text { GLS } & : \text { Generalised Least Square, } \\ \text { WLS } & : \text { Weighted Least Square, } \\ \text { MI } & : \text { Modification Index. }\end{array}$

In addition, binary logistic regression analysis is used to determine the relationship between independent variables (X) and binary scale response variables. Logistic regression analysis generally applies explanatory variables, which can be categorical or binary, to estimate the magnitude of an event opportunity based on the response category variable. Typically, financiallyincluded respondents assign the value of 1, while financially-excluded respondents assign the value of 0 . This is based on the Bernoulli distribution with the following opportunity distribution functions: ${ }^{41}$

$$
f(Y=y)=\pi^{y}(1-\pi)^{1-y}
$$


Where $y \in 0,1$ and $\pi$ is an opportunity of a successful event $(y=1)$. If the occurrence of $\mathrm{Y}$ the response variable is $\mathrm{n}$, the chance of each event is the same, and each event is independent of each other, therefore $Y$ will refer to the Binomial distribution. ${ }^{42}$

The explanatory variables used in this research are socioeconomic (X1), financial literacy (X2), social influence (X3), religious commitment (X4), infrastructure (X5), product \& services (X6), human capital (X7), and policies and regulations (X8) toward the opportunity of being financially included (Y). A response variable (Y) is the categorical scale, customer and non-customer (binary scale 1/0). If the response variable in the regression analysis is generally a categorical scale, then regression analysis employed is logistic analysis.

\section{Survey Design and Measurement}

In this research, the respondents (both financially-included and financiallyexcluded respondents) were asked to identify which determinant factors may influence their access to Islamic financial services. The items of constructs were evaluated using five levels of Likert scale: "1: strongly disagree"; "2: disagree"; "3: neutral"; "4: agree"; and "5: strongly agree". The higher the score, the greater the degree that the respondents will access Islamic financial services. Figure 2 illustrates the SEM model for this research.

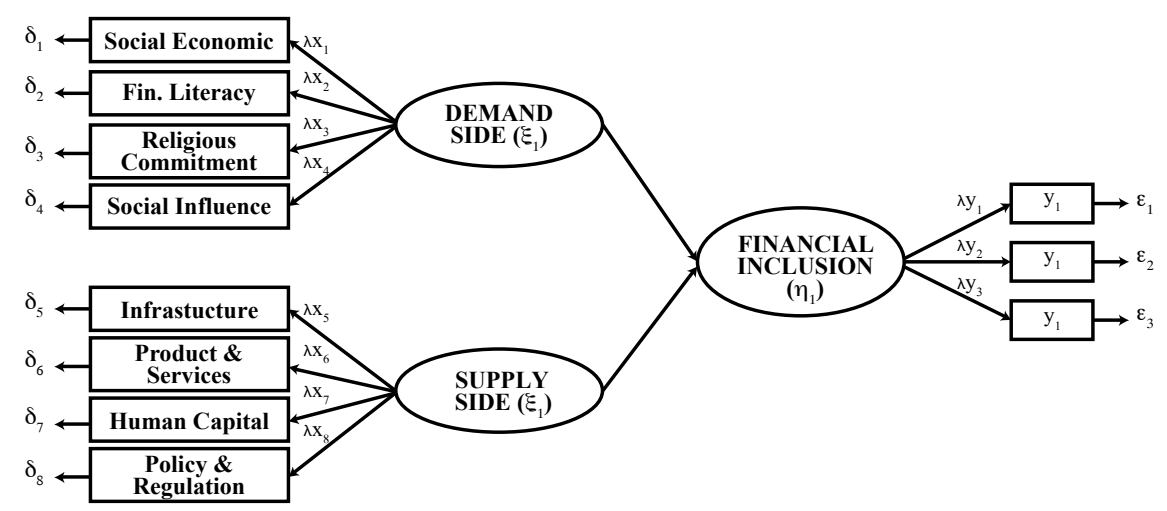

Figure 2: SEM Model of Financial Inclusion

Source: Authors 
Explanation:

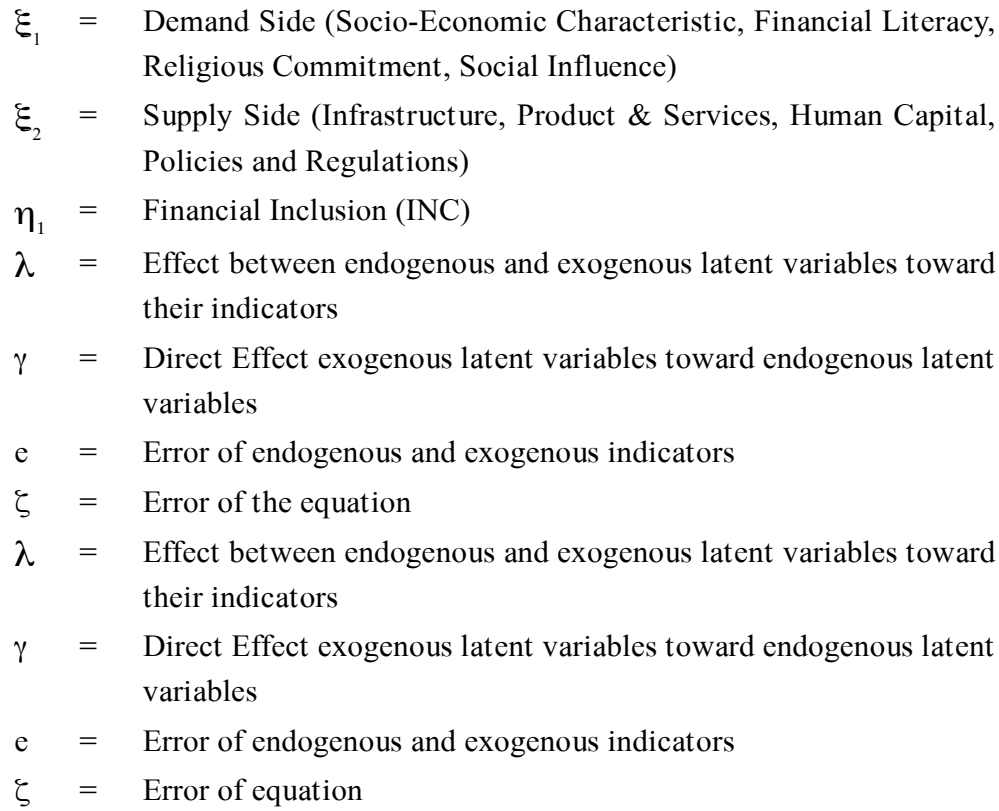

\section{Structural Equation}

$\eta_{1}=\gamma_{1} \xi_{1}+\gamma_{2} \xi_{2}+\xi_{1}$

Exogenous Variable Latent of Demand Side's Equation:

$\mathrm{X}_{11}=\lambda_{11} \xi_{1}+\mathrm{e}_{11}$

$\mathrm{X}_{12}=\lambda_{12} \xi_{1}+\mathrm{e}_{12}$

$\mathrm{X}_{13}=\lambda_{13} \xi_{1}+\mathrm{e}_{13}$

$\mathrm{X}_{14}=\lambda_{14} \xi_{1}+\mathrm{e}_{14}$

Exogenous Variable Latent of Supply Side's Equation:

$\mathrm{X}_{21}=\lambda_{21} \xi_{2}+\mathrm{e}_{21}$

$\mathrm{X}_{22}=\lambda_{22} \xi_{2}+\mathrm{e}_{22}$

$\mathrm{X}_{23}=\lambda_{23} \xi_{2}+\mathrm{e}_{23}$

$\mathrm{X}_{24}=\lambda_{24} \xi_{2}+\mathrm{e}_{2}$

Endogenous Variable Latent of Financial Inclusion's Equation:

$\mathrm{Y}_{1}=\lambda_{1} \eta_{1}+\lambda_{2} \eta_{1}+\lambda_{3} \eta_{1}+\mathrm{e}_{1}$ 
The observed variable in this research consists of eleven indicators (account ownership, the purpose of account use, the frequency of transaction, socio-economic, financial literacy, religious commitment, social influence, infrastructure, products and services, human capital, policies and regulation). Table 2 shows the operational variables of this study.

\begin{tabular}{|c|c|c|c|}
\hline Variable & Measurement & Author(s) & Scale \\
\hline \multicolumn{4}{|c|}{ Endogenous Variable } \\
\hline \multirow[t]{3}{*}{ Financial Inclusion } & Account ownership & \multirow{3}{*}{$\begin{array}{l}\text { Allen, et al (2012); } \\
\text { Kunt \& Klapper } \\
\text { (2013); Zins \& Weill } \\
\text { (2016) }\end{array}$} & \multirow{3}{*}{$\begin{array}{l}5 \text { point Semantic } \\
\text { differential }\end{array}$} \\
\hline & $\begin{array}{l}\text { Purpose of account } \\
\text { use }\end{array}$ & & \\
\hline & $\begin{array}{l}\text { The frequency of } \\
\text { transaction. }\end{array}$ & & \\
\hline \multicolumn{4}{|c|}{ Exogenous Variable } \\
\hline \multirow[t]{4}{*}{ Demand Side } & Socio-economic & \multirow{4}{*}{$\begin{array}{l}\text { Allen, et al (2012); } \\
\text { Clamara, Pena } \\
\text { \&Tuesta (2014); } \\
\text { Naceur, Barajas } \\
\text { \&Massara (2015); } \\
\text { Zins \& Weill (2016); } \\
\text { Clamara,et al (2014) }\end{array}$} & \multirow{4}{*}{$\begin{array}{l}\text { Nominal and Binary } \\
\text { Scale }\end{array}$} \\
\hline & Financial Literacy & & \\
\hline & $\begin{array}{l}\text { Religious } \\
\text { Commitment }\end{array}$ & & \\
\hline & Social influence & & \\
\hline \multirow[t]{4}{*}{ Supply Side } & Infrastructure & \multirow{4}{*}{$\begin{array}{l}\text { Allen, et al (2012); } \\
\text { Clamara, Pena } \\
\text { \&Tuesta (2014); } \\
\text { Naceur, Barajas } \\
\text { \&Massara (2015); } \\
\text { Zins \& Weill (2016); } \\
\text { Clamara,et al (2014) }\end{array}$} & \multirow{4}{*}{$\begin{array}{l}\text { Nominal and Binary } \\
\text { Scale }\end{array}$} \\
\hline & Product and service & & \\
\hline & Human capital & & \\
\hline & $\begin{array}{l}\text { Policies and } \\
\text { regulation }\end{array}$ & & \\
\hline
\end{tabular}

Table 2: Operational Variables

Source: Authors

\section{Results and Discussions}

\section{Sample Characteristics}

Table 3 summarises the sample characteristics based on seven categories: (i) gender, (ii) age, (iii) occupation, (iv) education, (v) marital status, (vi) income per month, and (vii) province and living area. As indicated in part 1, we use the primary data from 300 samples from a field survey on five major islands in Indonesia. However, nine samples were incomplete and thus excluded from the analysis. As a result, the total number of samples to be analysed in this study is 291 samples. 


\begin{tabular}{|c|c|c|c|}
\hline No & Items & Categories & Valid Percent (\%) \\
\hline 1 & Gender & $\begin{array}{l}\text { Male } \\
\text { Female }\end{array}$ & $\begin{array}{l}52.2 \% \\
47.8 \%\end{array}$ \\
\hline 2 & Age & $\begin{array}{l}21 \text { years old } \\
21-30 \text { years old } \\
31-40 \text { years old } \\
41-50 \text { years old } \\
51-60 \text { years old } \\
61-70 \text { years old } \\
-71 \text { years old }\end{array}$ & $\begin{array}{l}2.10 \% \\
35.10 \% \\
32.00 \% \\
21.60 \% \\
6.90 \% \\
2.10 \% \\
0.30 \%\end{array}$ \\
\hline 3 & Occupation & $\begin{array}{l}\text { Entrepreneur } \\
\text { Employee } \\
\text { Entrepreneur and Employee } \\
\text { Unemployed }\end{array}$ & $\begin{array}{l}33.00 \% \\
54.30 \% \\
7.90 \% \\
4.80 \%\end{array}$ \\
\hline 4 & Education & $\begin{array}{l}\text { Uneducated } \\
\text { Elementary } \\
\text { Middle/Junior } \\
\text { Senior } \\
\text { Diploma } \\
\text { Bachelor } \\
\text { Master } \\
\text { Doctoral }\end{array}$ & $\begin{array}{l}1.00 \% \\
4.50 \% \\
5.20 \% \\
35.10 \% \\
6.50 \% \\
40.90 \% \\
6.20 \% \\
0.70 \% \\
\end{array}$ \\
\hline 5 & Marital Status & $\begin{array}{l}\text { Unmarried } \\
\text { Married } \\
\text { Divorced } \\
\text { Widow/Widower }\end{array}$ & $\begin{array}{l}32.30 \% \\
66.00 \% \\
1.00 \% \\
0.70 \% \\
\end{array}$ \\
\hline 6 & Income per month & $\begin{array}{l}\text { Rp. } 1.000 .000 \\
\text { Rp. } 1.000 .000 \text { - Rp. } 1.700 .000 \\
\text { Rp. } 1.700 .000 \text { - Rp. } 2.500 .000 \\
\text { Rp. } 2.500 .000 \text { - Rp. } 5.500 .000\end{array}$ & $\begin{array}{l}17.50 \% \\
14.40 \% \\
12.40 \% \\
55.70 \% \\
\end{array}$ \\
\hline 7 & $\begin{array}{l}\text { Province \& Living } \\
\text { Area }\end{array}$ & $\begin{array}{l}\text { West Java } \\
\text { South Sulawesi } \\
\text { Aceh } \\
\text { North Maluku } \\
\text { East Kalimantan }\end{array}$ & $\begin{array}{l}71.50 \% \\
12.00 \% \\
7.60 \% \\
3.80 \% \\
5.20 \%\end{array}$ \\
\hline
\end{tabular}

Table 3: Descriptive Statistics of the samples $(n=291)$

According to table 3, there were 114 males (52\%) and 105 females (48\%), indicating a fair gender contribution across the data set. The majority of respondents $(66 \%)$ were married, $41 \%$ had a bachelor's degree, most of them are employed (54\%), and 35\% were between the ages of 21 and 30. Majority of respondents (56\%) earn a monthly income between IDR 2,500,000 to IDR $5,500,000$, and most of them reside in West Java province (72\%). 
In the subsequent sections, the results of the study are presented in two parts: (i) SEM results of financial inclusion determinants, and (ii) Binary logistics results of financial inclusion determinants.

\section{The Determinants of Islamic Financial Inclusion}

This section describes the result of the SEM model which is combined with the logistic regression method. SEM is used to determine the first order of CFA $\left(1^{\text {st }}\right.$ CFA) which represents the relationship between indicators and their dimensions. Logistic regression, on the other hand, is used to answer the hypothesis.

\section{SEM Results}

The $1^{\text {st }}$ CFA model is divided into two categories: the demand-side and supply-side - the demand-side consists of four main dimensions, namely (i) socioeconomic, (ii) financial literacy, (iii) religious commitment, and (iv) social influence. All measured indicator variables are significantly caused by the demand-side, except for the socioeconomic (see figure 3 ). The results show that financial literacy has the highest loading factor $(0.77)$, followed by religious commitment $(0.68)$, and social influence $(0.51)$, respectively. Some studies suggested that the loading factor value must be above 0.6. Other studies, on the other hand, argued that the value of loading factor can be $\geq 0.5$. FornellLarcker criterion for convergent validity requires the standardised loading factor (SLF) not less than $0.5 .{ }^{43}$ Hair et al criterion shares the same opinion with Fornell-Larcker that the SLF can be $\geq 0.5 .{ }^{44}$ Socioeconomic, on the other hand, provides an insignificant influence on financial inclusion from the demand side. Based on the financial literacy measurement model, fintech awareness has the highest loading factor $(0.76)$, followed by financial behaviour $(0.71)$, financial self-efficacy (0.68), media use (0.61), financial knowledge (0.54), and financial education (0.44), respectively. The religious commitment measurement model indicates that commitment to worship has the highest loading factor (1.00), followed by fear of divine punishment (0.98), perception of interest (0.90), commitment to using interest-free products $(0.63)$, barrier to finding interestfree transactions (0.15), and religious affiliation (0.09). According to the social influence measurement model, the influence of informal leaders has the highest loading factor (0.86), followed by community influence ( 0.85$)$, friend influence $(0.79)$, media influence $(0.75)$, family influence $(0.72)$, and culture influence (0.69).

The supply-side consists of four main aspects: (i) infrastructure, (ii) products and services, (iii) human capital, and (iv) policies and regulations. The 
supply side has a significant influence on all measured indicator variables, with products and services contributing the highest loading factor $(0.87)$, followed by human capital (0.81), policies and regulations (0.77), and infrastructure (0.75). There are six (6) indicators for each aspect. The infrastructure measurement model indicates that network connectivity has the highest loading factor (0.94), followed by fintech readiness (0.92), mobile infrastructure (0.82), distribution channel (0.60), location (0.46), and distance (0.41). The products and services measurement model demonstrate that safety has the highest loading factor (0.87), followed by product fit and transparency (0.81), transaction cost (0.80), and documentation requirements and collateral (0.78). The human capital measurement model indicates that KPI targeting has the highest loading factor (0.91), followed by social awareness (0.99), employment background (0.87), understanding and knowledge (0.85), educational background (0.73), and risk-taking behaviour (0.72). Lastly, the policies and regulation measurement model signifies that distribution policy has the highest loading factor (0.94), followed by fintech regulation ( 0.90$)$, consumer protection policy $(0.88)$, data infrastructure (0.84), literacy regulation (0.76), and incentives and initiatives (0.75). Figure 3 and Figure 4 illustrate the path diagram of the Islamic financial inclusion determinants.

Confirmatory Factor Analysis (CFA) value allows us to derive critical information about the most important determinant factor of the study. Since financial literacy has been identified as the most important determinant factor of financial inclusion from the demand side, people with more knowledge about finance are more likely to be financially included. From the supply side, the highest determinant factor are products and services. Therefore, if financial institutions can provide products and services that meet people's need, the possibility of them becoming financially included increases.

The significance level used in this study is 10 per cent, with a confidence interval of 90 per cent. The table in figure 4 evaluates the estimation of the constant value of the cumulative logistic opportunity for financial inclusion, where financially-included respondents (individual and enterprises) are assigned a value 1 and financially-excluded respondents (individual and enterprises) are assigned a value 0 . This is due to the fact that cumulative opportunity of dependent variables is valued at 1 . The logistic regression shows that the intercept (constant) has a value of 0.835930 , and a $p$-value of 0.000 , using the following formula:

$$
\ln \left(\frac{p}{1-p}\right)=0.835930
$$



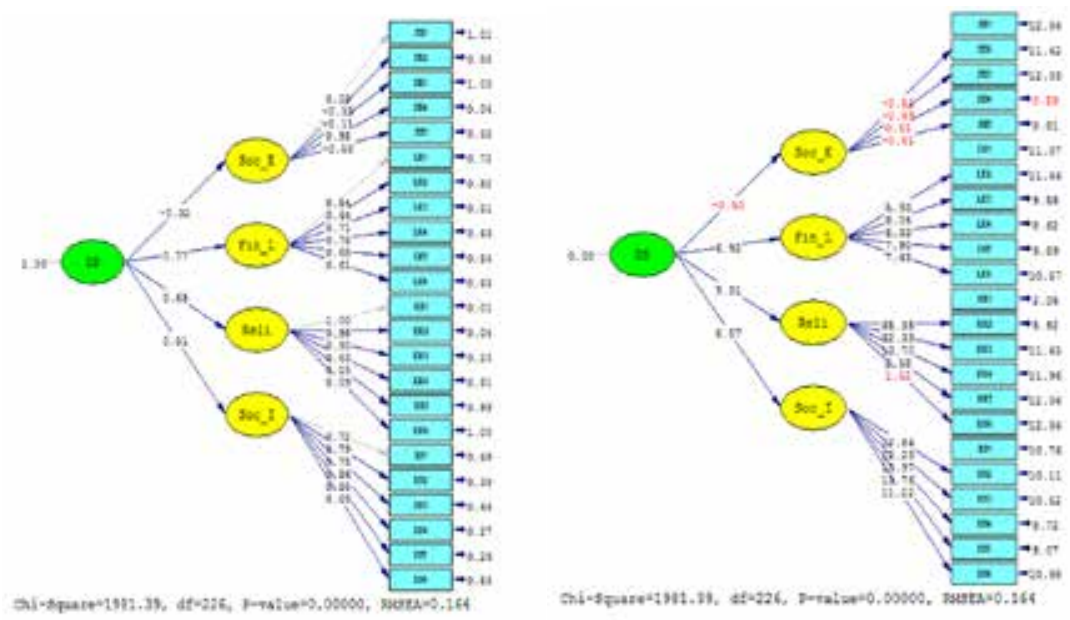

Figure 3: Standardised Solution and T-Value of 1st CFA Demand-Side (Overall Model) Source: Authors
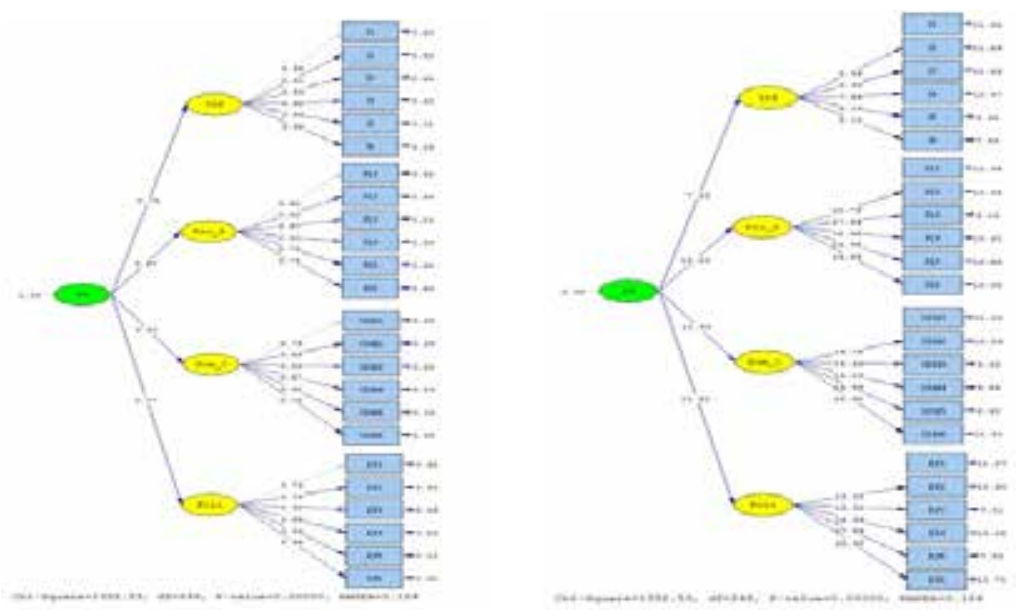

\begin{tabular}{|c|c|c|c|c|}
\hline Human_C & -0.619574 & -2.25 & 0.025 & 0.54 \\
\hline Policies_R & 0.176838 & 0.67 & 0.505 & 1.19 \\
\hline
\end{tabular}

Figure 4: Standardised Solution and T-Value of 1st CFA Supply-Side (Overall Model) Source: Authors 
Among the eight proposed hypotheses (socio-economic, financial literacy, religious commitment, social influence, infrastructure, product service, human capital, and policies and regulations), three independent variables (financial literacy, social influence, and human capital) have the most significant impacts on Islamic financial inclusion. Surprisingly, social influence dominates the impacts with a significant positive level of coefficient value of 0.96 and odds ratio of 2.61 or exp. (0.96). This indicates that the strong social influence will increase the chance of Islamic financial inclusion. The proportion of strong social influence (0.617) is greater than the weak social influence $(0.382)$.

Additionally, financial literacy has a positive and significant effect on Islamic financial inclusion with the coefficient value of 0.569 and odds ratio of 1.77 (significance level at 0.012 ). This means that better financial literacy on Islamic finance will increase the probability of financial inclusion by 1.77 times compared to a community with low financial literacy. Human capital also has a significant effect on financial inclusion with a coefficient value of -2.25 and an odds ratio of 0.54 (significance level 0.025). The negative coefficient of -2.25 and odds ratio of 0.54 indicate that human capital has a relatively minimal influence on Islamic financial inclusion as compared to other variables.

A goodness-of-fit test is obtained using three methods, Pearson (0.174), Deviance (0.055), and Hosmer-Lemeshow (0.004), which indicate that $p$-value $>\alpha$, or even closer to 1 (see table 4 ). This result suggests that the model perfectly matches the data. On this note, we may conclude that the empirical data obtained is suitable for the research.

\begin{tabular}{|c|c|c|c|}
\hline Method & Chi-Square & DF & P \\
\hline Pearson & 304.194 & 282 & 0,174 \\
\hline Deviance & 321.050 & 282 & 0,055 \\
\hline Hosmer-Lemeshow & 22.704 & 8 & 0,004 \\
\hline
\end{tabular}

Table 4: Goodness-of-fit tests of Islamic Financial Inclusion

\section{Discussions}

As indicated earlier, the research applies SEM and Binary Logistic Regressions methods to identify the most important determinants of Islamic financial inclusion in Indonesia. The former method was employed to obtain a response from the low-income segment (either financially-excluded or financiallyincluded) on the factors that may influence them to use Islamic financial services. Whereas, the latter was used to estimate the relationship between exogenous 
latent variables factors (demand side: socio-economic, financial literacy, religious commitment, and social influence, and supply-side: infrastructure, product and service, human capital and policies and regulators) and endogenous latent variables (financial inclusion).

SEM and binary logistic regression provide similar results when the same determinant variables are used. Using the SEM method, it is found that financial literacy, religious commitment, and social influence are the three most important demand-side determinants of Islamic financial inclusion. Meanwhile, binary logistic results indicate that financial literacy and social influence are the most important demand-side determinants. Surprisingly, from both methods, the socio-economic factor is not a significant determinant of Islamic financial inclusion. This finding contradicts earlier research, which claims that socioeconomy has a significant influence on financial inclusion. ${ }^{45}$ This is possibly due to the fact that if low-income individuals become bankable, they may prefer to use conventional financing rather than Islamic finance. Arguably, the former takes a more proactive approach than the latter, particularly in rural areas, thus making the low-income segment more exposed to conventional finance than Islamic finance. In some cases, any income surplus will be invested in real sectors which offer a higher return. Even if they decide to place their fund in a formal financial institution; they will choose the one that is more accessible, offers competitive returns, and has simpler procedures.

Under the financial literacy cluster, both methods have proven that financial literacy is the most crucial determinant of Islamic financial inclusion in Indonesia. Unfortunately, Islamic banks in Indonesia do not adopt a proactive approach to promote financial literacy and awareness among low-income populations, making it difficult for them to participate in Islamic banks. This recommends that the key stakeholders, especially informal leaders, should engage in a more active campaign and awareness programmes.

Next, the SEM results also revealed that fintech awareness is the most crucial factor of financial literacy. This is understandable, given that society favours financial services with a simple process. Fintech platforms (both Islamic and conventional) have been widely promoted in society, especially among millennials. ${ }^{46}$ Although many low-income people are unaware of fintech, ${ }^{47}$ integrating traditional financial services and technology will eventually influence them to use financial services, including Islamic financial services. ${ }^{48}$ Based on a survey by the World Bank, nearly 71 per cent of Indonesian adults are likely to make or receive digital payments. ${ }^{49}$ As a result, fintech integration by Islamic financial service will enable low-income groups and unbanked segments in Indonesia to access financial products and services. ${ }^{50}$ Furthermore, financial literacy is the main driver of financial inclusion in Indonesia. ${ }^{51}$ 
The SEM results show that informal influencers' (ustadz, kiyai, sheikh) impact is the most prominent component in social influence. Religious affiliation (i.e. Nahdlatul Ulama and Muhammadiyah) was found to be the least significant factor of Islamic financial inclusion. This finding suggests that people of all religions and communities are equally receptive to awareness programmes on Islamic finance. The analysis also found that fear of divine punishment and commitment to worship are the two most important determinants of Islamic financial inclusion in Indonesia. This finding confirms previous studies that suggests 'faith premium' influences financial decisions. However, due to a lack of knowledge and awareness, many low-income people believe that participating in conventional financial institutions has no religious implications. ${ }^{52}$

From the supply side, SEM discovered that the two most important determinants of Islamic financial inclusion are human capital, as well as products and services. Meanwhile, from the supply-side perspective, binary logistic results show that human capital is the most critical factor. In terms of products and services, the two methods' analysis indicated that product fit and safety are the two most important factors of Islamic financial inclusion in this cluster. Surprisingly, simple documentation requirements and collateral flexibility are less important determinants of Islamic financial inclusion. One possible explanation is that, in general, many Indonesian financial institutions have offered simple procedures and documentation requirements. This finding contradicts previous research, which identified collateral and documentation requirements as the two significant barriers to financial inclusion. ${ }^{53}$

In terms of the human capital cluster, analysis has found that Islamic finance talents should be instilled with a high level of social awareness as a minimum requirement. The finding verified previous studies $^{54}$ that indicated social awareness and attitudes are important KPIs in evaluating the competitiveness of IFI employees.

\section{Conclusion and Policy Recommendations}

This study is the first attempt to investigate the determinants of Islamic financial inclusion in Indonesia based on responses from both the financially included and the financially excluded segments of society.

Using SEM and binary logistic regression, the research discovered that financial literacy and social influence are the two most important determinants of Islamic financial inclusion from the demand side while human capital is the most significant determinant from the supply-side. The results also discovered that the influence of informal influencers' (ustadz, kiyai, sheikh) in the social- 
influence cluster is the most critical factor in promoting Islamic financial inclusion among the low-income segment of society.

According to the research, Islamic financial institutions should develop systematic approaches and strategies to enhance financial literacy and awareness of the low-income segment to participate in Islamic banking and financial services by: (i) actively engaging them with informal leaders (ustadz, kiyai, sheikh), (ii) introducing sustainable community-based education programmes, and (iii) incorporating fintech components. Additionally, the efforts of Islamic financial institutions and policymakers must focus on strengthening human capital competencies and skills through training and education, capacity development, and social awareness programmes. Also, his research suggests that the Indonesian government promote Islamic financial literacy beginning at the primary level of education

\section{Notes}

* Mohammad Mahbubi Ali, is Head of Economics, Finance, Awqaf and Zakat cum Associate Fellow at the International Institute of Advanced Islamic Studies Malaysia, Kuala Lumpur, Malaysia and Lecturer at Institut Agama Islam Tazkia, Bogor, Indonesia. Email: mahbubi@iais.org.my.

** Abrista Devi, is a lecturer at Ibn Khaldun University, Bogor, Indonesia.

*** Hamzah Bustomi, is a lecturer at Pakuan University, Bogor, Indonesia.

**** Muhammad Rizky Prima Sakti, is an Assistant Professor (Islamic Finance) at Department of Business Administration, University College Bahrain (UCB).

***** Hafas Furqani, is a Senior Lecturer at Universitas Islam Negeri Ar-Raniry, Banda Aceh, Indonesia.

This paper is part of a research project funded by the Central Bank of Indonesia - Bank Indonesia Institute under the Research Grant Bank Indonesia Programme 2018.

1. Demirguc-Kunt, Measuring Financial Inclusion around the World, Policy Research Working Paper, WPS7255 (Washington, D.C.: World Bank, 2015).

2. Fernando Aportela, Effects of Financial Access on Savings by Low-Income People (1999); Aycinena Ashraf, Martinez A., and Yangm, Remittances and the Problem of Control: A Field Experiment Among Migrants from El Savador (University of Michigan: Dupas and Robinson, 2009).

3. Md Ezazul Islam, 'Financial Inclusion in Asia and the Pacific,' The First High-Level Follow-up Dialogue on Financing for Development in Asia and the Pacific Conference (UNESCAP, Korea, 2016).

4. Annamaria Lusardi, Financial Capability in the United States: Consumer Decision-Making and the Role of Social Security, Research Paper 2010 
(Michigan Retirement Research Center, 2010), 226.

5. Mahmoud Mohieldin, Ahmed Rostom, Mahmoud Mohieldin, Xiaochen Fu, and Zamir Iqbal, The Role of Islamic Finance in Enhancing Financial Inclusion in Organization of Islamic Cooperation (OIC) Countries (Washington: World Bank, 2011).

6. Asli Demirguc-Kunt, Leora Klapper, Dorothe Singer, Saniya Ansar, and Jake Hess, 'The Global Findex Database 2017: Measuring Financial Inclusion and Opportunities to Expand Access to and Use of Financial Services,' The World Bank Economic Review 34, no. 1 (2020): S2-S8.

7. Asyraf Wajdi Dusuki, Mohammad Mahbubi Ali, Lokmanulhakim Hussain, A Framework for Islamic Financial Institutions to Deal with Shari 'ah Noncompliant Transactions (KuaIa Lumpur: ISRA, 2012).

8. Masudul Alam Choudhury, 'Financial Globalization and Islamic Financing Institutions: The Topic Revisited,' Islamic Economic Studies 9, no. 1 (2001).

9. International Monetary Fund, The Core Principle for Islamic Finance Regulations and Assessment Methodology. IMF Policy Paper, May 2018. Washington, D.C, 1-2.

10. 'Survei Nasional Literasi dan Inklusi Keuangan 2019,' Otoritas Jasa Keuangan. Available at: http://www.ojk.go.id/id/berita-dan-kegiatan/ siaranpers/Documents/Pages/Siaran-Pers-OJK-Indeks-Literasi-dan-InklusiKeuangan-Meningkat/buku\% 20statistik_172911.pdf. (Accessed on: 8 September 2021).

11. Demirguc-Kunt and Leora Klapper, 'Measuring Financial Inclusion: Explaining Variation In Use of Financial Services Across and Within Countries,' Brookings Papers on Economic Activity no. 1 (2013): 279-340; Kimutai, Factor Influencing, 2015; Alexandra Zins and Laurent Weill, 'The Determinants of Financial Inclusion in Africa,' Review of Development Finance 6, no. 1 (2016): 46-57; Ani Caroline Grigion Potrich, Kelmara Mendes Vieira, and Wesley Mendes-Da-Silva, 'Development of a Financial Literacy Model for University Students,' Management Research Review (2016).

12. Lukman Oyelami, Olufemi M. Saibu, and Babatunde S. Adekunle, 'Determinants of Financial Inclusion in Sub-Sahara African Countries,' Covenant Journal of Business and Social Sciences 8, no. 2 (2017).

13. Franklin Allen, Asli Demirguc-Kunt, Leora Klapper and Maria Soledad Martinez Peria, The Foundations of Financial Inclusion: Understanding Ownership and Use of Formal Accounts. Policy Research Working Paper 6290. The World Bank Development Research Group Finance and Private Sector Development Team; Kostov et al., Accces to Financial. 2015; Zins and Weill, The Determinants of Financial, 2016; Muhamed Zulkhibri, 'Financial Inclusion, Financial Inclusion Policy and Islamic Finance,' Macroeconomics and Finance in Emerging Market Economies 9, no. 3 (2016): 303-20; M. Kabir Hassan, Shadiya Hossain, and Omer Unsal, 'Religious Preference and Financial Inclusion: The Case for Islamic Finance,' in Management of Islamic Finance: Principle, Practice, and Performance, ed. M.K. Hassan and M. Rashid (Bingley: Emerald Publishing Limited, 2018).

14. Beck et al., Banking Services, 2008; Allen et al., The Foundations, 2012; Kimutai, Factors Influencing, 2015; Naceur et al, Can Islamic Banking, 2015; 
Kostov et al., 2015; Zins and Weill, The Determinants of Financial, 2016.

15. Allen et al. The Foundations of, 2012

16. Clamara, Pena and Tuesta, Factors that Matter, 2014; Zins and Weill, The Determinants of Financial, 2016.

17. Kostov et al., Access to Financial, 2015.

18. Kimutai, Factors Influencing, 2015.

19. Luigi Guiso, Michael Haliassos and Tullio Jappelli, Household Portfolios: An International Comparison (Cambridge: MIT Press, 2002); Rachel M. McCleary and Robert J. Barro, 'Religion and Economy,' Journal of Economic Perspectives 20, no. 2 (2006): 49-72; Paul Gerrans, Marilyn Clark-Murphy and Keith Truscott, 'Financial Literacy and Superannuation Awareness of Indigenous Australians: Pilot Study Results,' Australian Journal of Social Issues 44, no. 4 (2009): 417-39; Feisal Khan, 'How 'Islamic' is Islamic Banking?' Journal of Economic Behavior \& Organization 76, no. 3 (2010): 805-20; Zulkhibri, Financial Inclusion, 2016; Hassan et al., Religious Preference, 2019.

20. Guiso et al., Household Portfolios, 2002; McCleary \& Barro, Religion and Economy, 2004.

21. Guiso et al., Household Portfolios, 2002.

22. McCleary \& Barro, Religion and Economy.

23. Khan, 'How 'Islamic' is Islamic banking?'

24. Zulkhibri, Financial Inclusion.

25. Hassan et al., Religious Preference.

26. Allen et al. The Foundations of; Kimutai, Factors Influencing, 2015; Zins \& Weill, The Determinants of Financial, 2016.

27. Kimutai, Factors Influencing, 2015

28. Zins \& Weill, The Determinants of Financial, 2016.

29. Allen et al. The Foundations of, 2012

30. Raviadaran, H., Dastane, O., Ma'arif, M. Y., \& Mohd Satar, N. S. (2019). 'Impact of Service Quality Dimensions on Internet Banking Adoption, Satisfaction and Patronage,' International Journal of Management, Accounting and Economics 6 (10).

31. Son, Y., Kwon, H. E., Tayi, G. K., \& Oh, W., 'Impact of Customers' Digital Banking Adoption on Hidden Defection: A Combined Analytical-empirical Approach,' Journal of Operations Management 66, no. 4 (2020): 418-40; Chauhan, V., Yadav, R., \& Choudhary, V., 'Analyzing the Impact of Consumer Innovativeness and Perceived Risk in Internet Banking Adoption: A Study of Indian Consumers,' International Journal of Bank Marketing (2019); Jebarajakirthy, C., \& Shankar, A. 'Impact of Online Convenience on Mobile Banking Adoption Intention: A Moderated Mediation Approach,' Journal of Retailing and Consumer Services 58 (2021).

32. Tran, H. T. T., \& Corner, 'The Impact of Communication Channels on Mobile Banking Adoption,' International Journal of Bank Marketing (2016).

33. Bontis, N., \& Fitz-enz, J. 'Intellectual Capital Roi: A Causal Map of Human Capital Antecedents and Consequents,' Journal of Intellectual Capital (2002).

34. Arora, R. U., \& Ratnasiri, S. Financial Development, Financial Inclusion and Human Capital: How Close is the Link? A Study Of India. Indian Economy 
Update (Canberra: Australian National University, 2011); Ascarya, 'The Root Causes of Financial Crisis in Islamic Economic Perspective using Structural Equation Modeling.' Paper presented at $10^{\text {th }}$ International Conference on Tawhidi and World-System: God Conscious Organization and Conscious Social Order, Organized by IIH-UKM, RCIEF-FEM-UKM, and IEF Trisakti, University of Indonesia, Kuala Lumpur, December 27-28, 2013.

35. Chen, R., \& Divanbeigi, R. Can Regulation Promote Financial Inclusion? World Bank Policy Research Working Paper, (8711) (2019).

36. Peterson K. Ozili, 'Impact of Digital Finance on Financial Inclusion and Stability,' Borsa Istanbul Review 18, no. 4 (2018): 329-40.

37. 'Survei Nasional Literasi dan Inklusi Keuangan 2019,' Otoritas Jasa Keuangan. Available at: https://www.ojk.go.id/id/berita-dan-kegiatan/ publikasi/Pages/Survei-Nasional-Literasi-dan-Inklusi-Keuangan-2019.aspx. Accessed on: 8 September 2021.

38. www.bps.go.id

39. Ascarya Ascarya, Dudy Iskandar, 'The Root Causes of Financial Crisis.'

40. Ibid.

41. David W Hosmer, Borko Jovanovic, and Stanley Lemeshow, 'Best Subsets Logistic Regression,' Biometrics 45, no. 4 (1989): 1265-70.

42. Ibid.

43. Claes Fornell and David F. Larcker, 'Evaluating Structural Equation Models with Unobservable Variables and Measurement Error,' Journal of Marketing Research 18, no: 1 (1981): 39-50.

44. Joseph F. Hair, Marcelo Luiz Dias da Silva Gabriel and Vijay K. Patel, 'AMOS Covariance-Based Structural Equation Modelling (CB-SEM): Guidelines on its Application as a Marketing Research Tool,' Brazilian Journal of Marketing 13, no. 2 (2014): 44-55.

45. Allen et al., The Foundations of, 2012; Clamara, Pena \& Tuesta, Factors that Matter, 2014, Naceur et al, Can Islamic Banking, 2015; Zins and Weill, The Determinants of Financial, 2016.

46. Richard Duncombe, 'An Evidence-Based Framework for Assessing the Potential of Mobile Finance in Sub-Saharan Africa,' The Journal of Modern African Studies 50, no. 3 (2012): 369-95.

47. Nasrul Hakim Ghazali and Takashi Yasuoka, 'Awareness and Perception Analysis of Small Medium Enterprise and Start-Up towards Fintech Instruments: Crowdfunding and Peer-To-Peer Lending in Malaysia,' International Journal of Finance and Banking Research 4, no. 1 (2018): 13.

48. Jane M. Kolodinsky, Jeanne M. Hogarth, and Marianne A. Hilgert, 'The Adoption of Electronic Banking Technologies by US Consumers,' International Journal of Bank Marketing (2004).

49. World Bank, Global Findex, 2017.

50. Manuchehr Shahrokhi, 'E-Finance: Status, Innovations, Resources and Future Challenges,' Managerial Finance 34, no. 6 (2008); M. Sravani, 'Role of Technology in Microfinance Sector in India,' International Journal of Social Science \& Interdisciplinary Research 2 no. 9 (2013): 107-11; Peterson K. Ozili, 'Impact of Digital Finance on Financial Inclusion And Stability,' Borsa Istanbul Review 18, no. 4 (2018): 329-40. 
51. Mohammad Mahbubi Ali, Abrista Devi, Hafas Furqani and Hamzah Hamzah, 'Islamic Financial Inclusion Determinants in Indonesia: An ANP Approach,' International Journal of Islamic and Middle Eastern Finance and Management 13 No. 4 (2020): 727-47.

52. Gerrans et al., Financial Literacy; Khan, How 'Islamic'is; Zulkhibri, Financial Inclusion; Hassan et al., Religious Preference, 2019.

53. Allen et al., The Foundations of, 2014; Beck et al., Banking Services, 2008.

54. Mark Loo, 'Attitudes and Perceptions towards Islamic Banking among Muslims and Non-Muslims in Malaysia: Implications for Marketing to Baby Boomers and X-Generation,' International Journal of Arts and Sciences 3, no. 13 (2010): 453-85.

\section{Bibliography}

Aduda, J., and Kalunda, E. 'Financial Inclusion and Financial Sector Stability with Reference to Kenya: A Review of Literature.' Journal of Applied Finance and Banking 2 no. 6 (2012): 95-120.

Allen, F., Demirguc-Kunt, A., Klapper, L and Peria. The Foundations of Financial Inclusion: Understanding Ownership and Use of Formal Accounts. Policy Research Working Paper 6290. The World Bank Development Research Group Finance and Private Sector Development Team.

Amin, Y., and Jalil, A. 'Remittances and Financial Inclusion: Micro-econometric Evidences from Pakistan.' Asian Journal of Economics, Business and Accounting (2017): 1-13.

Arora, R. U., and Ratnasiri, S. 'Financial Development, Financial Inclusion and Human Capital: How Close is the Link? A Study of India.' Paper presented in the Indian Economy Update 2011, Australian National University, Canberra, September 19, 2011.

Ascarya A., and Dudy Iskandar. 'The Root Causes of Financial Crisis in Islamic Economic Perspective using Structural Equation Modeling.' Paper presented at $10^{\text {th }}$ International Conference on Tawhidi and World-System: God Conscious Organization and Conscious Social Order, IIH-UKM, RCIEF-FEM-UKM, and IEF Trisakti, University of Indonesia, Kuala Lumpur, December, 2013.

Atkinson, A., and Messy, F. A. 'Assessing Financial Literacy in 12 Countries: An OECD/INFE International Pilot Exercise.' Journal of Pension Economics \& Finance 10 no. 4 (2011): 657-65.

Beck, T., Kunt, A.D., and Peria, M.S.M. 'Banking Services for Everyone? Barriers to Bank Access and Use around the World.' The World Bank Economic Review 22 no. 3 (2008): 397-430.

Chen, R., \& Divanbeigi, R. Can Regulation Promote Financial Inclusion? World Bank Policy Research Working Paper, (8711), 2019. 
Cheung, G. W.,and Wang, C. 'Current Approaches for Assessing Convergent and Discriminant Validity with SEM: Issues and Solutions.' In Academy of management Proceedings (Vol. 2017, No. 1, 12706). Briarcliff Manor, NY 10510: Academy of Management, 2017.

Clamara, N., Pena, X., and Tuesta, D. Factors That Matter for Financial Inclusion: Evidence From Peru. BBVA Research Working Paper No. 14/09, 2014.

Demirguc-Kunt, A., and Klapper, L. 'Measuring Financial Inclusion: Explaining Variation in Use of Financial Services Across and Within Countries.' Brookings Papers on Economic Activity 44 no.1 (2013): 279-340.

Demirguc-Kunt. Measuring Financial Inclusion around the World. Policy Research Working Paper, WPS7255. Washington, D.C.: World Bank.

Ellis, K., Lemma, A., \& Rud, J. P. Financial Inclusion. Household Investment and Growth in Kenya and Tanzania, Project Briefing (43), 2010.

Fornell, C., and Larcker, D.F. 'Evaluating Structural Equation Models with Unobservable Variables and Measurement Error.' Journal of Marketing Research 18 no. 1 (1981): 39-50.

Gerrans, P., Clark-Murphy, M., and Truscott, K. 'Financial Literacy and Superannuation Awareness Of Indigenous Australians: Pilot Study Results.' Australian Journal of Social Issues 44 no. 4 (2009): 417-39.

Ghazali, N. H., and Yasuoka, T. 'Awareness and Perception Analysis of Small Medium Enterprise and Start-up Towards FinTech Instruments: Crowdfunding and Peer-to-Peer Lending in Malaysia.' International Journal of Finance and Banking Research 4 no. 1 (2018).

Guiso, L., Haliassos, M., and Jappelli, T., eds. Household Portfolios. Cambridge: MIT press, 2002.

Hair, J.F., Jr, Gabriel, M.L.D., and Patel, V.K. 'AMOS Covariance-Based Structural Equation Modelling (CB-SEM): Guidelines on its Application as a Marketing Research Tool.' Brazilian Journal of Marketing 13 no. 2 (2014): 44-55.

Hassan, Hossain, and Unsal. 'Religious Preference and Financial Inclusion: The Case for Islamic Finance.' In Management of Islamic Finance: Principle, Practice, and Performance. Edited by M.K. Hassan and M. Rashid. Bingley: Emerald Publishing Limited, 2019.

Islam, M.E. Financial Inclusion in Asia and the Pacific. Thailand: Macroeconomic Policy and Financing for Development Division (MPFD), 2016.

Kabakova, O., and Plaksenkov, E. 'Analysis of Factors Affecting Financial Inclusion: Ecosystem View.’ Journal of Business Research 89 (2018): 198-205.

Koenig-Lewis, N., Marquet, M., Palmer, A., and Zhao, A. L. 'Enjoyment and Social Influence: Predicting Mobile Payment Adoption.’ The Service Industries Journal 35 no. 10 (2015): 537-54.

Kolodinsky, Hogarth and Hilgert. 'The Adoption of Electronic Banking Technologies 
by US Consumers.' International Journal of Bank Marketing 22 no. 4 (2004): 238-59.

Kostov, P., Arun, T, and Annim, A. 'Access to Financial Services: The Case of the 'Mzansi' Account in South Africa.' Review of Development Finance 5 (2015): 34-42.

Lusardi, A. (2010). Financial Capability in the United States: Consumer DecisionMaking and the Role of Social Security. Working Paper WP 2010-226.

Loo, M. 'Attitudes and Perceptions towards Islamic Banking among Muslims and Non-Muslims in Malaysia: Implications for Marketing to Baby Boomers and X-Generation.' International Journal of Arts and Sciences 3 no. 13 (2010): 45385 .

Mattaini, M. A. 'Ecosystems theory.' In Comprehensive Handbook of Social Work and Social Welfare, Vol. 2. Edited by B. A. Thyer, K. M. Sowers and C. N. Dulmus. United States: John Wiley \& Sons Inc. 2008.

Mattaini, M., and Meyer, C. 'The Ecosystems Perspective: Implications for Practice.' In The Foundations of Social Work Practice, $3^{\text {rd }}$ edn. Edited by M. Mattaini, C. Lowery and C. Meyer. Washington DC: NASW Press, 2002.

McCleary, R. M., and Barro, R. J. 'Religion and Economy.' Journal of Economic Perspectives 20 no. 2 (2006): 49-72.

Mindra, R., Moya, M., Zuze, L. T., and Kodongo, O. 'Financial Self-Efficacy: A Determinant of Financial Inclusion.' International Journal of Bank Marketing 35, no. 3 (2017): 338-53.

Mindra, R., and Moya, M. 'Financial Self-Efficacy: A Mediator in Advancing Financial Inclusion.' Equality, Diversity and Inclusion: An International Journal 36 no. 2 (2017):128-49.

Mohieldin, M., Iqbal, Z., Rostom, A., and Fu, X. (2011). The Role of Islamic Finance in Enhancing Financial Inclusion in Organization of Islamic Cooperation (OIC) Countries. Policy Research Working Paper 5920.

Naceur, M. S. B., Barajas, M. A., and Massara, M. A. Can Islamic Banking Increase Financial Inclusion? (No. 15-31). International Monetary Fund (2015).

Naeem, M. 'Developing the Antecedents of Social Influence for Internet Banking Adoption through Social Networking Platforms: Evidence from Conventional and Islamic Banks.' Asia Pacific Journal of Marketing and Logistics, 2020.

'Survei Nasional Literasi dan Inklusi Keuangan 2019.' Otoritas Jasa Keuangan. Available at: http://www.ojk.go.id/id/berita-dan-kegiatan/siaranpers/Documents/ Pages/Siaran-Pers-OJK-Indeks-Literasi-dan-Inklusi-Keuangan-Meningkat/ buku\% 20statistik_172911.pdf.

Oyelami, L.O., Saibu, O.M., and Adekunle, B. S. 'Determinants of Financial Inclusion in Sub-Sahara African Countries.' Covenant Journal of Business \& Social Sciences (CJBSS) 8 no. 2 (2017). 
Ozili, P. K. 'Impact of Digital Finance on Financial Inclusion and Stability.' Borsa Istanbul Review 18, no.4 (2018): 329-40.

Pepinsky, T. B. 'Development, Social Change, and Islamic Finance in Contemporary Indonesia.' World Development 41 (2013): 157-67.

Potrich, A. C. G., and Vieira, K. M. 'Demystifying Financial Literacy: A Behavioral Perspective Analysis.' Management Research Review (2018).

Potrich, A. C. G., Vieira, K. M., and Mendes-Da-Silva, W. 'Development of a Financial Literacy Model for University Students.' Management Research Review 39, no. 3 (2016): 356-76.

Raviadaran, H., Dastane, O., Ma'arif, M. Y., and Mohd Satar, N. S. 'Impact of Service Quality Dimensions on Internet Banking Adoption, Satisfaction and Patronage.' International Journal of Management, Accounting and Economics 6, no. 10 (2019).

Swamy, V. 'Financial Inclusion, Gender Dimension, and Economic Impact on Poor Households.' World Development 56, 1-15.

Tran, H. T. T., and Corner, J. 'The Impact of Communication Channels on Mobile Banking Adoption.' International Journal of Bank Marketing 34, no. 1 (2016): 78-109.

Umar, A.I. 'Index of Syariah Financial Inclusion in Indonesia.' Buletin Ekonomi Moneter dan Perbankan 20, no. 1 (2017): 99-126.

Wijanto, S. H. Structural Equation Modeling dengan Lisrel 8.8: Konsep dan Tutorial. Jakarta: Salemba Empat, 2008.

World Bank. Global Financial Development Report: Financial Inclusion. Washington, D.C: The World Bank (2014).

World Bank. Global Findex Database. Washington DC: The World Bank, 2017.

Zins, A., \& Weill, L. 'The Determinants of Financial Inclusion in Africa.' Review of Development Finance 6 (2016): 6-57.

Zulkhibri, M. 'Financial Inclusion, Financial Inclusion Policy and Islamic Finance.' Macroeconomics And Finance in Emerging Market Economies 9 No. 3 (2016): 303-20. 